Crop Breeding and Applied Biotechnology S2: 57-66, 2012

Brazilian Society of Plant Breeding. Printed in Brazil

\title{
ARTICLE
}

\section{Plant breeding in the semiarid region of Brazil: examples of success}

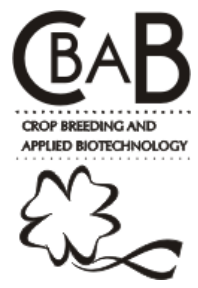

Manoel Ab́lio de Queiroz ${ }^{*}$, Levi de Moura Barros², Luiz Paulo de Carvalho ${ }^{3}$, Jonas de Araújo Candeia ${ }^{4}$ and Edinardo Ferraz

Received 15 September 2012

Accepted 03 October 2012

\begin{abstract}
The Northeastern region of Brazil comprises the Caatinga biome $\left(900,000 \mathrm{~km}^{2}\right)$ part of which is a semiarid region with rainfed and irrigated production systems. Among the successful breeding programs are cashew and cotton. The first led to a substantial increase in nut production in Ceará, Rio Grande do Norte and Piaui and the second bred a naturally colored cotton fiber, now processed in small clothing industries in Paraiba, exporting to 11 countries. In the lower-middle São Francisco valley, the previously grown onion was replaced by improved varieties, on $90 \%$ of the production area, and by industrial tomato, introduced by research in 1972, which came to be used on more than $80 \%$ of the area at the time. The participation of the private sector and continuity of breeding programs were crucial for the success. More examples of success are expected with the establishment of postgraduate courses in Agricultural Sciences in the Semiarid region.
\end{abstract}

Key words: Anacardium occidentale, Gossypium hirsutum, Allium cepa, Lycopersicum esculentum.

\section{INTRODUCTION}

The Northeastern region of Brazil covers an area of 1.6 million $\mathrm{km}^{2}$, in 10 states, including northern Minas Gerais and several biomes. The largest biome is the Caatinga (xeric shrubland and thorn forest), with about $900,000 \mathrm{~km}^{2}$ and a predominantly semi-arid environment. The average rainfall in this ecosystem varies from $400 \mathrm{~mm}$ in the driest, to $800 \mathrm{~mm}$ in the wetter places; the aridity index is 0.5 (balance between precipitation and evaporation) and the drought risk $60 \%$ (Valente Junior 2010). A large part is used for rainfed agriculture, especially livestock production, with drought-tolerant forages as well as perennial crops. Irrigated areas are found at different points where water is available in the Semiarid region, mostly along the São Francisco River, where agricultural systems with fruit trees and vegetables are exploited.

However, in most cases, be it annual or perennial plants, the varieties used in the most diverse agricultural activities in the region had not been developed for a semiarid climate, but were merely introduced. Thus, to achieve adequate production levels, an adjustment to the environmental conditions is required, when possible. For example, pests and diseases in vegetables can be controlled by chemical products, or phytohormones can induce uniform budding as occurs in grape vine, or delay growth and induce flowering in mango, among others (Vieira et al. 2010).

Alternatively to these measures, better-suited varieties can be developed for cultivation in semiarid regions, for rainfed or irrigated cultivation, and consequently reduce the dependency on environmental adjustment. Therefore, breeders should be integrated in the different regional research institutions, which is not always the case, because the research support of these institutions, mainly of those of the state, was always affected by great instability and often the breeding work was and still is being abandoned. In general, the situation is critical in any field of knowledge, however, it is highly limiting in the case of plant breeding. Additionally, the location of the Federal Universities further aggravates the problem. In almost all states of northeastern Brazil, the universities are located along the coast, so that at the beginning of the last decade, the quota of doctors specialized in the semiarid ecozone corresponded to only one tenth of the number of $\mathrm{PhD}$ graduates from universities, with serious implications for the development of contextual

\footnotetext{
${ }^{1}$ Universidade do Estado da Bahia, Departamento de Tecnologia e Ciências Sociais, Av. Edgard Chastinet Guimarães, s/n, São Geraldo, 48.905-680, Juazeiro, BA, Brazil. *E-mail: manoelabiliomaq@gmail.com

${ }^{2}$ Empresa Brasileira de Pesquisa Agropecuária, Centro Nacional de Pesquisa de Agroindústria Tropical, Rua Dra. Sara Mesquita, 2.270, Pici, 60.511-110, Fortaleza, CE, Brazil

${ }^{3}$ Empresa Brasileira de Pesquisa Agropecuária, Centro Nacional de Pesquisa de Algodão, Rua Osvaldo Cruz 1143, Centenário, CP 174, 58.107-720, Campina Grande, PB, Brazil

${ }^{4}$ Instituto Agronômico de Pernambuco, Departamento Técnico Científico, Estação Experimental de Belém do São Francisco, IPA Rural, 56.440-000, Belém de São Francisco, PE, Brazil
} 
research for the semiarid region. Nevertheless, a few breeding programs were developed in the past four decades and, unlike the vast majority of processes initiated by institutions, these were not interrupted and produced impressive results. Four examples of successful plant breeding in the semiarid region were chosen for this representation: the improvement of two crops under rainfed conditions, namely cashew, with a great response in the states of Ceará, Rio Grande do Norte and Piauí and colored cotton in the state of Paraíba; and breeding of two irrigated vegetable crops in the São Francisco Valley, i.e., onion and industrial tomato.

\section{Cashew breeding}

The economic exploitation of the cashew tree, a plant native to Brazil, is concentrated in the states of Ceará, Piauí and Rio Grande do Norte. These states account for $91 \%$ of the national production, on 700,000 ha (IBGE 2012) (IBGE, http://www.ibge.gov.br/home/). This area includes different biomes, ranging from the Coastal Tablelands to the Caatinga, the part with least rainfall, which shows the excellent adaptation of this crop to the semiarid conditions. Cashew generates more than 160 million dollars a year in foreign exchange, mainly by exports of the key product, the raw cashew nut, since the participation of cashew shell oil (liquid from the cashew nut shell - CNSL) is small. However, the value of the retail sale of cashew products reaches about two billion dollars. This translates to about 16,000 direct jobs created in urban areas and 300,000 men day $^{-1} \mathrm{yr}^{-1}$ in rural areas, almost all in the harvest period, equivalent to 42,000 jobs yr $^{-1}$ (Barros et al. 1999, Crisóstomo et al. 1999).

Research was taken up between 1940 and 1950 and was marked by the importance of the CNSL as the main product and the transformation of the peduncle, the secondary product, into various subproducts. As of 1956, plants were collected from natural populations, especially the species Anacardium occidentale L., from both common cashew and early dwarf cashew trees. Seed samples were collected from 124 accessions and more than 3,000 common cashew plants and from 21 plants of 8 dwarf cashew accessions in Maranguape, Ceará (CE), which were planted at the Experimental Station Pacajus, CE (Barros et al. 1999). Several other collections, some of seeds, some of vegetative propagules, were established in $1979,1995,1998$, resulting in a collection of a total of 496 accessions and more than 4,200 plants. However, more than $85 \%$ of the accessions belong to the species A. occidentale $\mathrm{L}$. and the remaining $15 \%$ belong to accessions of other species, e.g., A. microcarpum Ducke, A. humile Mart. (Barros et al. 1999). According to the same authors, the samples were collected in several counties of the states of Ceará, Rio Grande do Norte and Piauí, while a few introductions of the Cerrado and the Amazon are included, as well as introductions from India and Venezuela. The Experimental Station Pacajus, initially of the Ministry of Agriculture, was later transferred to the Agricultural Research Corporation of Ceara (EPACE), and in 1988 to Embrapa, and lastly turned into the National Cashew Research Center (CNPCa). More recently, the center was integrated in the Embrapa Tropical Agroindustry, headquartered in Fortaleza (Almeida et al. 1993). As shown, the cashew breeding work began in the mid-1950s, which was some time before the foundation of Embrapa, and is going on until today.

The 1960s and 1970s were marked by large commercial plantations resulting from a cashew expansion program fostered by government incentives. In these plantations, only common cashew was used, grown directly from seeds or from ungrafted seedlings planted in defined spacings.

Subsequently, clones of common and early dwarf cashew were obtained and evaluated (set of plants originated from a common genotype, i.e., with the same genetic background), leading to the recommendation of the Pacajus cashew clones (CCP series). This work began in 1965 at the Experimental Station Pacajus and led to the development of the clones CCP 06 and CCP 76, in 1983, and of CCP 09 and CCP 1001, in 1987, all early dwarf cashew, for commercial production. Of these, clone CCP 06 is noteworthy, selected in 1979 from the matrix or mother plant CP 06 (CP for Pacajus Cashew), after 15 years of evaluation at the station. The highest recorded yield of this matrix was $25 \mathrm{~kg}$ plant $^{-1}$ of nuts, on low-fertility, sandy soil, without liming, fertilization or pest control. Clone CCP 76 was also selected in 1979 from the matrix CP 76 and also evaluated for 15 years in Pacajus-CE. The highest yield of CP 76 was $22 \mathrm{~kg} \mathrm{plant}^{-1}$, under the same conditions as clone CP 06 . The rootstock can be either A. microcarpum or, preferably, the proper early cashew species (A. occidentale). In this way, the cashew breeding program solved the problem of the plant height. The short stature facilitates management practices such as pruning and pest and disease control, which are difficult, if not altogether infeasible in practical and economic terms, for tall trees. The canopy uniformity is important for a coherent arrangement of the plants according to the population density determined for each clone, with positive effects on the orchard management and yield. The improved clones of early dwarf cashew in irrigated cultivation produce up to 30 $\mathrm{kg}$ of fruits per plant in the first year, which already allows harvesting when the production is destined for table-fruit 
market. Moreover, in terms of yield, the improved clones reached a production of more than $1,000 \mathrm{~kg}$ of nuts under rainfed conditions, compared with the $220 \mathrm{~kg}$ produced on plantations of unimproved clones of common cashew (Barros et al. 1998, 1999, Crisóstomo et al. 1999).

The partnership with the private sector created conditions for the evaluation of a large number of clones in the production areas and thereby reduced the time needed until a final recommendation, allowing a rapid dissemination of the described clones.

\section{Breeding of colored cotton}

Naturally colored cotton originated in ancient America, where brown cotton types were used since the domestication some 4,500 years ago by the Aztec and Inca Indians, as well as by other ancient peoples of the Americas, Asia, Africa, and Australia (Freire 1999). In China, researchers have selected brown-fiber cultivars (Xiao et al. 2007). However, the fiber characteristics of colored cotton are always inferior to those of white lint.

Recently, the interest in colored cotton lint grown on family farms in Northeastern Brazil has increased, produced in both conventional and organic managements. This is mainly due to the fact that the farmer can sell the colored fiber at a better price than white cotton. The natural color valorizes environment-friendly products, sparing artificial dying, which pollutes the environment. Furthermore, if produced organically, without chemical inputs and fertilizers, the crop has a high commercial value. To meet this demand, Embrapa Algodão, headquartered in Campina Grande, PB, since the mid-1980s, has continuously carried out breeding projects with the purpose of selecting colored fiber cultivars, with high yield and good lint quality. The breeding program was initiated by the researcher Eleusio Curvelo Freire, who began a germplasm collection in 1984 in Patos, Paraíba, of cotton trees of colored lint from seeds collected in Acari-RN and Milagres-CE (Freire 1999). These matrices had light brown fiber. Initially, 11 accessions were evaluated and it was found that they had very fine fiber, with low uniformity and low resistance, and lack of stabilization of the fiber hues. These problems were addressed in the breeding program, using individual selection with progeny tests (Freire 1999). This line of improvement culminated in the release of BRS 200, which began to be planted in 2000 and, being derived from colored cotton native to semiarid climate, has a three-year cycle and is quite drought-tolerant.

Another part of the breeding program used hybridization as breeding method based on the variety CNPA 7H, with great adaptability to the semiarid climate, and $G$. hirsutum L gene donors with colored fiber, introduced from other countries (Carvalho et al. 2011). In 1996, the genotype Arkansas Green with green fiber was crossed with CNPA 7H, followed by two more backcrosses with CNPA $7 \mathrm{H}$ to recover some fiber characteristics of this parent. The resulting population was subjected to pedigree or genealogical selection, aiming at improved fiber traits, mainly for fiber resistance, which was low in the greencolored donor. After several selection cycles and comparison tests, the resulting three lines in bulk originated BRS Verde, released in 2003. The fiber color of BRS Verde is instable, since the green color pigments are sensitive to sunlight. Due to this characteristic, it is recommended that the fiber be collected in two stages, in a first and a second harvest, to prevent the fiber from being exposed too long to the sun in the field. Some characteristics of this cultivar were compared with one of its parents, the white fiber CNPA 7H (Table 1). The fiber length of BRS Verde is intermediate (about $30 \mathrm{~mm}$ ), similar to the white fiber cultivar CNPA 7H. The fiber resistance is approximately [19] $26 \mathrm{~g} \mathrm{tex}^{-1}$. The cycle of BRS Verde is similar to that of CNPA 7H, with 130-140 days; under rainfed conditions, its yield was lower than that of CNPA 7H (Table 1), but satisfactory.

Table 1. General characteristics of the colored-fiber cotton cultivar BRS Verde in comparison with the white cotton cultivar CNPA $7 \mathrm{H}^{1}$

\begin{tabular}{lcc}
\hline Characteristics & BRS Verde & CNPA 7H \\
\hline Resistance ( $\left.\mathrm{g} \mathrm{tex}^{-1}\right)$ & 25.86 & 26.71 \\
Fiber length (upper-half mean) & 29.56 & 30.98 \\
Cycle (days) & $130-140$ & $130-140$ \\
$1^{\text {st }}$ boll (days) & 92 & 90 \\
Flower and pollen color & Cream & Cream \\
Mean height (m) & 1.27 & 0.77 \\
Yield (kg ha $\left.{ }^{-1}\right)$ & 2.146 & 2.480 \\
\hline
\end{tabular}

${ }^{1}$ Average data from dryland experiments.

Another cross was also made in 1996, of a dark brown fiber genotype, from the Active Germplasm Bank (BAG), Embrapa Agodão, and CNPA 7H, a white-fiber upland cotton with good quality, adapted to the semiarid conditions in the Northeast. From the $\mathrm{F}_{3}$ generation onwards, a genealogical selection program began for the breeding objectives dark brown fiber, good yield and good-quality fiber. After several selection cycles, lines were obtained that participated in comparison tests at a number of locations in the Northeast, where line CNPA 01-22 performed especially well in relation to dark brown fiber and yield and was released in 2005, as BRS Rubi. This cultivar differs from the others in a dark brown or reddish-brown fiber color. As 
all colored fiber cultivars, prolonged exposure to the sun must be avoided to obtain intense fiber coloration (see Table 2 for a list of characteristics of BRS Rubi).

Table 2. General characteristics of the colored-fiber cotton cultivar BRS Rubi in comparison with the white cotton cultivar CNPA $7 \mathrm{H}^{1}$

\begin{tabular}{lcc}
\hline Characteristics & BRS Rubi & CNPA 7H \\
\hline Yield $\left(\mathrm{kg} \mathrm{ha}^{-1}\right)$ & 1.871 & 1.755 \\
Fiber percentage & 35.6 & 37.2 \\
Fiber length (upper-half mean) & 25.4 & 29.4 \\
Resistance (g tex ${ }^{-1}$ ) & 24.5 & 28.6 \\
Fineness (micronaire) & 3.7 & 3.4 \\
Uniformity (\%) & 81 & 85 \\
\hline
\end{tabular}

${ }^{1}$ Average data from dryland experiments.

The yield potential of BRS Rubi is good, with higher production than CNPA $7 \mathrm{H}$ in the tests under rainfed conditions (Table 2). This cultivar is intended in the first place for the Northeast, where disease incidence is low. In spite of the high productivity, some fiber characteristics such as fiber percentage, length and resistance fall short of the ideal standards for a cultivar with intermediate fiber, although these characteristics have not affected the spinning performance. Carvalho and Santos (2003) reported the difficulty of selecting colored-fiber genotypes because of the negative correlations between color and good fiber quality.

Also from the hybridization process, a plant with beige fiber was selected from a segregating population of multiple crosses of herbaceous cotton. The colored types of this selection had better fiber quality, equal to or even better than the white-fiber types, of which BRS Topázio was released in 2010 .

\section{Onion breeding for irrigated areas of the lower- middle São Francisco valley}

The onion crop occupies an area of 58,482 ha in the country, on which 1,325,000 t or an average yield of $23 \mathrm{t}$ $\mathrm{ha}^{-1}$, are produced, varying between 50.8 and $18.8 \mathrm{tha}^{-1}$. It is the third most consumed vegetable in the world and Brazil is the eighth largest producer. Production is distributed in three main regions of Brazil, namely: South (Santa Catarina, Rio Grande do Sul and Paraná) with 784,000 t; Southeast (Minas Gerais and São Paulo) with 288,000 t; and Northeast (Bahia and Pernambuco) with 279,000 t (IBGE, http://www.ibge.gov.br/home/).

It is worth noting that Portuguese immigrants introduced the yellow onions, constituting the Baia Periforme germplasm, derived from populations of a Portuguese onion called Garrafal in Rio Grande do Sul (Barbieri 2008) and were mainly cultivated in the municipalities around Rio Grande. According to the author, a late genotype called Pêra Norte by the Azorean people, an African germplasm, was introduced in the Azores and from there brought to Brazil. Its cultivation was established in São José do Norte in Rio Grande do Sul. In the state of Santa Catarina, in the Upper Valley of the Itajai River, the Crioula type was selected, possibly originating from a cross between the populations Baias Periformes and Pêra Norte. The selected types had globose bulbs, nut-brown shell or purple bulbs (Barbieri 2008).

In the region of the lower middle São Francisco in the Northeast of Brazil, irrigated onion cultivation began in the 1940s, with the variety Amarela Chata das Canárias. This variety had been brought from Santa Cruz de Tenerife, Canary Islands, was introduced in the municipalities Cabrobó and Belém do São Francisco, in Pernambuco and then spread across several municipalities in the São Francisco Valley, in the states of Pernambuco and Bahia. However, despite the good adaptation to irrigated farming, being a short-day variety, the post-harvest storage of the bulbs was low, the bulb shape flattened, and highly susceptible to the anthracnose fungus (Colletrotricum gloesporioides Penz.), and to purple blotch (Alternaria porri (Ellis) Ciferri). Moreover, the seeds had to be imported, often with supply problems when required for planting and frequently of poor quality. Therefore, an onion breeding program had to be developed to try to solve these problems. In the early 1970s, inspired by Professor Marcílio de Souza Dias, Department of Genetics, College of Agriculture Luiz de Queiroz (ESALQ) in Piracicaba, SP, and with a freshly graduated breeder from the course of Genetics and Plant Breeding of that department, the breeding program was established, with support from the researcher Jorge Luiz da Gama Wanderley, coordinator of a broad research program in Vegetable Science at the Institute of Agronomic Research (IPA), today Agronomic Institute of Pernambuco (IPA), domiciled in Pernambuco, at the Experimental Stations of Belém do São Francisco and Vitória de Santo Antão. Thus, the two researchers at these locations established programs of onion breeding and seed production with short, medium and long-term strategies, as described by Wanderley et al. (1974).

It is important to mention that onion is biennial, i.e. in one cycle the crop produces bulbs and seeds in the next, so that the effect of stratified mass selection proposed by Gardner (1961) could be much more efficient than when applied to corn plants. Therefore, this was the main breeding method in the selection of onion in the proposed program. 
Secondly, the breeding program included the introduction of the germplasm Baia, with better bulb conservation, apart from other relevant germplasms of purple and yellow onions. The onions Baias Periformes were introduced that had already been improved in the yellow onion breeding program of the ESALQ genetics department. One of them was the onion Baia Periforme Precoce do Cedo. The second introduced germplasm was the Composto Baia, of the same department, which consisted of intercrosses of some Baia populations from Rio Grande do Sul, previously selected in Piracicaba. Another introduced germplasm was population Roxa Barreiros from the cultivation of red onions in Barreiros near Belo Horizonte, MG. Finally, several Baia populations were also introduced from seed producers in Rio Grande do Sul, which were evaluated for the lower middle São Francisco basin.

In this way, two selection cycles were performed with the populations of Baia do Cedo and Composto Baia, the first in 1972/73 and the second cycle in 1974/75. The seeds of the original populations and of the two selection cycles, along with the control Amarela Chata das Canárias were evaluated in a field experiment, according to the recommended seasonal onion cultivation techniques. The bulbs selected in each cycle were vernalized in a cold chamber at $8{ }^{\circ} \mathrm{C}$ for 60 days and the seeds were used to evaluate the effect of stratified mass selection in onion. The gains per selection cycle were around $5 \mathrm{tha}^{-1}$ for Baia do Cedo and $4.5 \mathrm{t} \mathrm{ha}^{-1}$ for Composto Baia. These experiments were described by Melo et al. (1978).

The selections in the two base populations (Baia do Cedo and Composto Baia) and a selection of another population from the germplasm Baia Periforme Precoce introduced in the Brazilian Northeast, called Baia Triunfo, after being selected at high temperatures, were evaluated in a second set of experiments, in three contrasting seasons: summer (November - March), when temperatures are highest in the Lower middle São Francisco valley; traditional season of onion cultivation in the region (February - July) and in a season with milder temperatures (April - September). In all experiments, the application of stratified mass selection proved effective in increasing the commercial bulb yield (gains of $5 \mathrm{tha}^{-1}$ per cycle) and in reducing unproductive plants and early bulb formation, whereas yield of the selections of Baia germplasm populations was not significantly different from the control Amarela Chata das Canárias. It was also found that the selection of Baia Triunfo at high temperatures resulted in the selection of season-specific types that were not suited for cultivation in other seasons, indicating genotype - environment interaction (Menezes et al. 1979, Menezes et al. 1981).
Thus, in 1980, the best selections of the program, designated IPA 1 and IPA 2, were released, indicated for planting from February to June, which came to be widely cultivated by the farmers. However, these two varieties were replaced by a variety resulting from intercrosses of 10 Baia Periforme populations, designated Composto IPA 6, which was released in 1985 and was widely cultivated for several years. Also, in another experimental cycle, a Baia Periforme population was subjected to seven selection cycles in cultivation without fungal control of anthracnose and purple blotch, under environmental conditions favorable to the disease onset, giving rise to a population with high tolerance to anthracnose and black spot, released in 1992 as IPA 9.

The population Roxa de Barreiros of the introductions was initially poorly adapted to the conditions of the lower-middle São Francisco basin, but in the experiments of 1974, some bulbs were formed and selected and after a few selection cycles gave rise to a population adapted to cultivation in warm periods. This cultivar was released in 1983 as Roxa IPA 3, which was planted for several years. The cultivar was resistant to the fungus Colletrotrichum gloesporioides Penz. (Costa et al. 1974) as well as to onion thrips (Thrips tabaci Lindeman).

Later, the varieties IPA 9 and Roxa IPA 3 were crossed, followed by a few cycles of stratified mass selection in segregating populations, leading to the release of Vale Ouro IPA 11, in 1997. This yellow onion variety was widely accepted by farmers and until today it is the main cultivar in irrigated areas of the semiarid region of Brazil. Another approach was the intercross of the red variety Red Creole, with flattened bulbs and highly anthracnose-susceptible, with the variety Roxa IPA 3, which after a few cycles of stratified mass selection in segregating populations led to the cultivar released as Franciscana IPA 10, in 1995, which is still the main variety produced in the segment of purple onions.

\section{Breeding of industrial tomato for the Northeastern region of Brazil}

The industrial tomato in the country was marked by a breakthrough based on work developed by the Indústrias Peixe, domiciled in Pesqueira, Pernambuco, initiating activities of progeny testing of varieties in the late 1920s. These studies were conducted by Agronomist Moacyr Britto de Freitas, who became production manager and later managing director of the industrial group Pesqueira. After a few years of selection and competition, he produced the variety Beauty Peixe, originated from North 
America. This variety was grown on a commercial scale for several years, but in the mid-1960s was attacked by a major outbreak of late blight caused by the fungus Phytophthora infestans (Mont.) de Bary (Melo 1998). Due to the impossibility of bringing the disease under control, the crop became unfeasible and Agronomist Moacyr left Indústria Peixe in 1969.

Professor Marcilio Dias, who claimed that the Lowermiddle São Francisco was an appropriate region to produce high-quality tomato paste due to the low humidity, provided seed tomato varieties from different industrial breeding programs (France, Italy and United States) and the field experiments were initiated in 1972 at the IPA Experimental Station, in Belém do São Francisco. The experiments were carried out by the above breeder and the researcher Luiz Jorge da Gama Wanderley, both from IPA. Nearly 100 entries were evaluated in this first stage, of which one part was evaluated in a period of milder temperatures (May-August) and the other at higher temperatures (September-December) of the same year (Dias et al. 1973). Among these introductions cultivar Rossol was notable, obtained by the Institut National de la Recherche Agronomique (INRA) in France, due to the fruit characteristics suitable for the industry and for resistance to nematode galls, Meloidogyne sp., commonly occurring in sandy and silty soils of irrigated fluvic Neosols in the lower-middle São Francisco valley. While large numbers of galls were observed on the roots of the variety Santa Cruz, Rossol proved fully resistant, with absolutely clean roots. On the other hand, Rossol aborted a great number of flowers in the high- temperature experiment.

Since the evaluations were accompanied by tomato processing companies (Indústrias Peixe and Companhia Industrial de Conservas Alimentícias - CICA), they rapidly purchased seed of variety Rossol directly from INRA and in the following year, the two companies were cultivating the variety in irrigated areas in the surroundings of Pesqueira, Pernambuco. This phase can be considered the first of a tomato breeding program for the industry, in which a set of two experiments was sufficient to convince companies to adopt the variety for large-scale cultivation, especially in the period of milder temperatures.

As a spin-off of the variety evaluations of 1972, increased tolerance to flower abortion was noted in the varieties La Bonita, Nova and M128 in the warm period, so all of them were selected for hybridizations with the variety Rossol, to develop nematode- and heat-resistant types. This breeding phase of industrial tomato represented the second stage of the breeding program, in which the $F_{1 s}$ generations were established and selection by the pedigree or genealogical method occurred in the segregating populations. This gave rise to the varieties IPA 1 and IPA 2 (Costa et al. 1978) and IPA 3, resulting from the cross of Rossol with M128, nematode-resistant and with good fruiting capacity at high temperatures. Variety IPA 3 also serves a dual purpose - fresh consumption and industrial use. However, the fruit consistency of these varieties was low, forcing the companies to work with fruits packed in boxes, which was unpractical for the handling of production. At this point, lines with fruit firmness were introduced, among which Cal J and PSX 76 were selected and both were crossed with variety IPA 3 . The cultivars IPA 5 and IPA 6 were established by hybridization and selection of segregating populations by the bulk method, respectively. These cultivars have been widely accepted and grown in irrigated areas of the lower-middle São Francisco basin. Some corrections were made in both cultivars, which were widely disseminated, since the fruit consistency is good, making boxes unnecessary.

Subsequently, the variety Viradouro was obtained in partnership with Embrapa Hortaliça, resulting from the intercross of IPA 5 with a source of resistance to the virus locally known as "vira-cabeça" TSW-10, male donor, which contains gene Sw-5 (Giordano et al. 1999). "Vira-cabeça" is caused by different tospovirusses, however, in the state of Pernambuco it is caused by the groundnut ring spot virus (GRSV) (Avila et al. 1996) and tomato spotted wilt virus (TSWV) (Lima et al. 2000). Importantly, the variety IPA 5 incorporated all gains of the previous selections, such as gall nematode resistance, foliar-disease and heat tolerance, and now resistance to "vira-cabeça".

However, the advent of the whitefly (Bemisia tabaci (Gennadius 1889)), vector of the geminivirus in the region, brought up a new challenge. The variety Viradouro was crossed with the resistance source LA 3473 consisting of a selection within populations, derived from a cross between L. chilense Dun. and L. esculentum Mill., with subsequent backcrossing to L. esculentum. This source is a carrier of the TY-1 gene that confers resistance to the tomato yellow leaf curl virus (TYLCV) (Ferraz et al. 2003). Six selection cycles of this cross were made in segregating populations using massal selection and developing a cultivar with resistance to "vira cabeça" and to the whitefly-transmitted viruses, released under the name Redenção (Ferraz et al. 2003). 


\section{DISCUSSION}

Importantly, the selected and described breeding programs have one feature in common, which is the long-standing continuity of all four, reaching nearly 50 years, as in cashew breeding, and up to 40 years in the breeding programs of onion and industrial tomato; only breeding of colored cotton began in the mid-1980s, and is therefore little older than 25 years. All of them relied on breeders who did most significant and lasting work. For example in cashew breeding, which was also affected by institutional shifts, but for being a perennial plant, the collection initiated in the mid-1950s remained and was enriched over the years and in the different institutions. The presence of the Embrapa breeders Levi de Moura Barros, João Ribeiro Crisóstomo and João Rodrigues Paiva, without underestimating the work of many others, was essential for the significant results and for the release of clones that are now grown on a large scale in cashew plantations in the states of Rio Grande do Norte, Ceará and Piauí. The future challenge will be the development of new clones with resistance to major biotic stresses and improving the quality of the pseudofruit, be it for juices or fresh use, which is a task for a new generation of breeders.

The cultivation of colored cotton fiber on a commercial scale began in 2002 in Paraíba, with the brown-fiber cultivar BRS 200, which was developed by researcher Eleusio Curvelo Freira of Embrapa Cotton. There was a demand in Europe and Japan for clothes made of fabric free of chemical dyes for use by newborns and people with a dye-allergy. To this end, small fields were initially planted. Due to the interest of small industries in the product, the planting area was increased. Some problems in the supply chain had to be solved, such as the plume processing, spinning and weaving, as the fiber volume was small compared to that of the white fiber and there was little interest of these industries due to the small plume volume. These problems were solved with the increasing demand for the product and today there are several small industries that spin and weave colored cotton in Paraiba aside from clothing industries that make clothes for Brazil and for exportation, one of which alone exports its products of colored-lint cotton to 11 countries.

The breeding work was carried on by the researcher Luiz Paulo Carvalho, also from Embrapa Cotton, who continued the program and developed and released cultivars with cream, brown and green fibers. However, other colors such as blue, are inexistent in this germplasm and the tendency is to obtain fiber with these colors in the future using biotechnology, as done in flowers. The production chain of colored cotton has created employment in the country and industry, of some importance in the economy of the state of Paraíba.

The onion breeding program of the Agronomic Institute of Pernambuco (IPA) caused a great impact, because in the main irrigated areas of the semiarid region, i.e., on about $90 \%$ of all onion plantations, the two main varieties of the program (IPA 10 and IPA 11) are grown, which are very well-adapted, with resistance to the major biotic stresses of the region. Coupled with the breeding, a seed production program of varieties was established with the private sector. Several family enterprises produce all the seed of the IPA series varieties, but the autonomous or cooperative farmers purchase the basic seed from the IPA. This process ensures an adequate maintenance of the characteristics of the varieties released by the research institution.

These varieties were the result of continued selection over years by breeders since the early 1970s, under the leadership of the researchers Luiz Jorge da Gama Wanderley and Manoel Abílio de Queiroz, who introduced the Baia germplasm from the collection of Professor Marcilio Dias. The researcher Luiz Jorge da Gama Wanderley supervised the entrance of the breeders Paulo César Tavares de Melo, Dimas Menezes and of Jonas Araújo Candeia, who is still active until today. However, in terms of yield, the varieties of the IPA series are less productive than the hybrids, with around $40 \mathrm{t} \mathrm{ha}^{-1}$ of commercial bulbs, while the hybrids produced over $50 \mathrm{t} \mathrm{ha}^{-1}$ (Bandeira 2010). It is likely that in the future, famers will seek access to hybrid seeds, although the price of these seeds might be unattractive for most of the farmers. On the other hand, the breeding work is being continued at Embrapa Semiarid, in Petrolina, PE, where the breeder Carlos Antonio Fernandes Santos is working towards the development of onion hybrids based on a divergence study between onion populations, in which populations from the IPA program were included. This breeder detected divergence between the populations and therefore, a basis for the development of lines for the synthesis of promising hybrids. The most important aspect is that these lines are resistant to the major biotic stresses of the irrigated semiarid areas (Santos et al. 2011).

Finally, similarly to the other programs, continuity was the main driving force in the improvement of industrial tomato. The initial germplasm, consisting of American, French and Italian varieties, was provided by Professor 
Marcilio de Souza Dias, in 1972. At that time, the breeder Edinardo Ferraz participated in the breeding program, using his vacation for a practical training while still an agronomy student, encouraged by the researcher Luiz Jorge da Gama Wanderley. He was enthusiastic about the possibility of selecting lines for nematode resistance and after graduation, he joined the IPA program as tomato breeder and remains active until the present. He is one of the few breeders in the country who maintained continuous activity for so long in the selection work of tomato lines. The dual-purpose tomato varieties IPA 5 and, particularly, IPA 6 , were grown in over $90 \%$ of commercial tomato plantations in irrigated semiarid areas. However, with the advent of irrigated fruit crops, the occurrence of pests in tomato and low yields in irrigated commercial plantations discouraged the processing industries, which moved on to the Brazilian Cerrado region in the late 1990s. However, the yield of IPA 5 and IPA 6 is also lower than the productivity of the currently grown hybrids, as reported by tomato growers, now producing primarily for fresh consumption. On the other hand, these varieties have excellent fruit characteristics and are resistant to the main biotic stresses of tomato, while the available hybrids are susceptible to most of them and, therefore, require large amounts of pesticides to reach a desirable production level. But then, there are many lines with homozygous resistance to several biotic stresses (nematode galls, leaf diseases, tospovirus and geminivirus, good plant and fruit traits) and it is likely that high-yielding hybrids could be obtained. Recently a new breeder, Dr. Mina Karasawa, was integrated in the IPA team to work towards the development of future cultivars, above all less pesticide-dependent, for irrigated agriculture in the semiarid region.

As pointed out, continuity was the key element in the success of these four breeding programs. Intermissions in this area have occurred in different breeding programs in the country, with devastating results. For example, the vegetable breeding program of the Department of Genetics of the College of Agriculture "Luiz Queiroz" (ESALQ) headed by Professor Marcilio de Souza Dias was given up and now, very little remains of the great contributions of the program. In northeastern Brazil, the breeding program of common bean (Phaseolus vulgaris L.) of the Agronomic Institute of Pernambuco - IPA conducted by the researcher Paulo Miranda, was also discontinued after his retirement and practically all his work was lost. Another very similar case occurred with Professor Josué Fernandes Pedrosa of the Federal Rural University of the
Semi-Arid (UFERSA), because the germination capacity of the seeds of the selected pumpkin (Cucurbita spp.) varieties was lost after his retirement and nothing could be saved. In fact, as mentioned by Watson (2005), it was the continuation of the selection process of the pioneer human populations over the course of 10 thousand years that resulted in the domestication of plants that feed the entire humanity today and which, according to the same author, is the greatest contribution to mankind.

In northeastern Brazil, the breeding work might continue on an increasing scale, in view of the changes occurring in the investment in infrastructure of postgraduate courses related to agricultural sciences, now existing at several locations in the Semiarid region (Sobral and Crato in Ceará; Mossoró in Rio Grande do Norte; Patos, Pombal and Areia in Paraíba; Serra Talhada and Garanhuns in Pernambuco; Juazeiro, Feira de Santana and Vitória da Conquista in Bahia; Janaúba in Minas Gerais). It is possible that some studies on the improvement of species relevant for the Semiarid region can be initiated, e.g., of forages and native fruits, and medicinal, ornamental and other species. The example of Genetic Resources Network of Bahia (Romão and Ramos 2005), now transformed into Genetic Resources Network of the Northeastern region (RGV Northeast) may be an encouraging element in the breeding process of different species, with the participation of teachers in several different postgraduate courses located at different points in the semiarid region, to make success stories become more common.

\section{ACKNOWLEDGEMENTS}

The authors thank the many breeders who have participated in the various programs and made the continuation of work on the four selected crops possible. In particular they wish to thank the researchers Francisco Pereira de Andrade and João Luis da Silva Filho for their collaboration in the breeding program of colored cotton; the researcher José Geraldo Eugênio de França for arranging for the introduction of tomato germplasm from the University of California; Judas Tadeu de Menezes for his effective participation in seed production of onion varieties released to farmers and Nivaldo Duarte Costa for the evaluation of varieties in different irrigated onion production systems in the lower-middle São Francisco. The authors are also indebted to the funding agencies of several breeding programs, particularly of the Superintendência de Desenvolvimento do Nordeste (SUDENE), Banco do Nordeste, Brascan Nordeste and the National Council for Scientific and Technological Development (CNPq) for scholarships. 


\section{Melhoramento de plantas no Semiárido brasileiro: alguns casos de sucesso}

Resumo - O Nordeste brasileiro engloba o bioma Caatinga (900 mil $\mathrm{km}^{2}$ ) onde se encontra a região Semiárida com sistemas de produção dependentes de chuva e irrigação. Dentre os programas de melhoramento que tiveram sucesso destacam-se o do cajueiro e do algodoeiro. O primeiro produziu aumento substancial na produção de castanhas no Ceará, Rio Grande do Norte e Piaui e o segundo resultou em fibra colorida processada em pequenas indústrias de confecção na Paraíba, com exportação para 11 países. No Submédio São Francisco, a cebola cultivada foi substituida pelas variedades melhoradas, cultivadas em $90 \%$ da área de produção, e o tomate industrial, introduzido pela pesquisa em 1972, foi cultivada em mais de 80\% da área, na época. A participação do setor privado e a continuidade dos programas de melhoramento foram determinantes para o sucesso dos mesmos. Esperam-se mais casos de sucesso com o estabelecimento de cursos de pós-graduação em Ciências Agrárias no Semiárido.

Palavra-chave: Anacardium occidentale, Gossypium hirsutum, Allium cepa, Lycopersicum esculentum.

\section{REFERENCES}

Almeida JIL, Araújo FE and Lopes JGV (1993) Evolução do cajueiro anão precoce na Estação Experimental de Pacajus, Ceará. EPACE, Fortaleza, 17p. (Documentos 6).

Ávila AC, Lima MF, Resende RO, Tozzer L, Ferraz E, Maranhão EAA, Candeia JA and Costa ND (1996) Identificação de tospovirus em hortaliças no Submédio São Francisco utilizando DAS-ELISA e dotELISA. Fitopatologia Brasileira 21: 503-508.

Bandeira GRL (2010) Produção de cultivares de cebola sob diferentes manejos de irrigação por gotejamento. Universidade do Estado da Bahia, Juazeiro, 56p. (PhD Thesis).

Barbieri RL (2008) Cebola: das lágrimas ao sabor. In Barbieri RL and Stumpf ERT (eds) Origem e evolução de plantas cultivadas. Embrapa Informação Tecnológica, Brasília, p. 253-264.

Barros LM, Paiva JR and Cavalcanti JJV (1999) Recursos genéticos de cajueiro: situação atual e estratégias para o futuro. In Queiroz MA, Goedert CO and Ramos SRR (eds) Recursos genéticos e melhoramento de plantas para o Nordeste brasileiro. Embrapa Semiárido (http://www.cpatsa.embrapa.br).

Barros LM, Paiva JR and Cavalcanti JJV (1998) Cajueiro-anão-precoce: melhoramento genético - estratégias e perspectivas. Biotecnologia, Ciência \& Desenvolvimento 6: 18-21.

Carvalho LP and Santos JW (2003) Respostas correlacionadas do algodoeiro com a seleção para a coloração da fibra. Pesquisa Agropecuária Brasileira 38: 79-83.

Carvalho LP, Andrade FP and Silva Filho JL (2011) Cultivares de algodão colorido no Brasil. Revista Brasileira de Oleaginosas e Fibrosas 15: $32-44$.

Costa CP, Fernandes FT and Fonseca JNL (1974) Resistência em cebola (Allium cepa L.) ao "mal de sete voltas" (Colletotrichum gleosporoides Penz). Revista de Olericultura 14: 24-25.

Costa CP, Ferraz E, Wanderley LJG, Melo PCT, Souto JPM, Lima DT, Queiroz MA, Candeias JA and Silva HM (1978) Tomate para indústria IPA 1-2. Pesquisa Agropecuária Pernambucana 2: 88-93.

Crisóstomo JR, Barros LM, Paiva JR and Cavalcanti JJ (1999) Melhoramento genético do cajueiro. In Queiroz MA, Goedert CO and Ramos SRR (eds) Recursos genéticos e melhoramento de plantas para o Nordeste brasileiro. Embrapa Semiárido (http://www.cpatsa.embrapa.br).
Dias MS, Queiroz MA, Costa CP, Wanderley LJG, Santos MAC, Yokoyama S and Lima DT (1973) Ensaio de cultivares de tomate (Lycopersicon esculentum Mill.) visando industrialização. Revista de Olericultura 13: 42-44.

Ferraz E, Resende LV, Lima GSA, Silva MCL, França JGE and Silva DJ (2003) Redenção: nova cultivar de tomate para a indústria resistente a geminivírus e tospovírus. Horticultura Brasileira 21: 578-580.

Freire EC (1999) Algodão colorido. Biotecnologia, Ciências e Desenvolvimento 9: 36-39.

Gardner CD (1961) An evaluation of effects of mass selection and seed irradiation with thermal neutrons on yield com. Crop Science 1: 241-246.

Giordano LB, Bezerra IC, Ferraz E, Ávila AC, Lima MF, Resende LV and Souza AJ (1999) Desenvolvimento de linhagens e cultivares de tomateiro para o Nordeste do Brasil com resistência a tospoviroses e geminiviroses. In Queiroz MA, Goedert CO and Ramos SRR (eds) Recursos genéticos e melhoramento de plantas para o Nordeste brasileiro. Embrapa Semiárido (http://www.cpatsa.embrapa.br).

Lima MF, Ávila AC, Resende RO and Nagata T (2000) Levantamento e identificação de espécies de tospovírus em tomateiro e pimentão no Submédio do Vale do São Francisco e no Distrito Federal. Summa Phytopatologica 26: 205-210.

Melo PCT (1998) Recursos genéticos e melhoramento de tomateiro industrial no Semiárido brasileiro. In Anais do $\mathbf{3 8}^{0}$ Congresso brasileiro de olericultura. Embrapa Semiárido/ Sociedade Brasileira de Olericultura/Superintendência de Desenvolvimento do Nordeste/ Bayer, Petrolina (CD ROM).

Melo PCT, Costa CP, Wanderley LJG, Menezes D and Queiroz MA (1978) Seleção massal em duas populações de cebola (Allium cepa L.) baia periforme no Vale do Submédio São Francisco. Pesquisa Agropecuária Pernambucana 2: 95-118.

Menezes D, Wanderley LJG, Queiroz MA and Melo PCT (1979) Eficiência da seleção massal nas adaptações de cebola (Allium cepa L.) ao cultivo de verão, no Submédio São Francisco. Pesquisa Agropecuária Pernambucana 1: 113-118.

Menezes D, Costa CP, Wanderley LGG, Candeia JA and Melo PCT (1981) Seleção de populações de cebola (Allium cepa 1 ) do grupo baia piriforme para época de cultivo, no Vale do Submédio São Francisco. Pesquisa Agropecuária Pernambucana 5: 05-20. 
MA Queiroz et al.

Romão RL and Ramos SRR (2005) Recursos genéticos vegetais no estado da Bahia. UEFS, Feira de Santana-BA, 231p.

Santos CAF, Oliveira VR, Rodrigues MA, Ribeiro HLC and Silva GO (2011) Similaridade genética entre cultivares de cebola de diferentes tipos e origens, baseada em marcadores AFLP. Horticultura Brasileira 29: 32-37.

Xiao YH, Zhang ZS, Yin MH, Luo M, Li XB, Hou L and Pei Y (2007) Cotton flavonoid structural genes related to the pigmentation in brown fibers. Biochemical and Biophysical Research Communications 358: 73-78.

Valente Junior AS (2010) Semiárido em transformação: panorama socioeconômico e entraves para o desenvolvimento In Batista Filho
M and Miglioli TC (Org.) Viabilização do semiárido do Nordeste: um enfoque multidisciplinar. Liceu, Recife, p. 69-81.

Vieira EL, Souza GS, Santos AR and Silva JS (2010) Manual de fisiologia vegetal. EDUFMA, São Luís, 186p.

Wanderley LJG, Queiroz MA, Melo PCT, Dias MS, Costa CP, Maia E, Souto JPM, Santos MAC and Lima DT (1974) Programa de melhoramento e produção de sementes de cebola (Allium cepa L.) para áreas do Submédio São Francisco. Revista de Olericultura 14: $26-29$.

Watson JD (2005) DNA: o segredo da vida. Companhia das Letras, São Paulo, 470p. 